East Tennessee State University

Digital Commons@ East Tennessee State University

ETSU Faculty Works

Faculty Works

$8-2016$

\title{
Geographical Location and Stage of Breast Cancer Diagnosis: A Systematic Review of the Literature
}

Faustine Williams

East Tennessee State University, williamsf2@etsu.edu

Aimee S. James

Washington University in St. Louis School of Medicine

Stephen Jeanetta

University of Missouri

Follow this and additional works at: https://dc.etsu.edu/etsu-works

Part of the Health Services Research Commons, Inequality and Stratification Commons, Oncology Commons, Race and Ethnicity Commons, Regional Sociology Commons, and the Women's Health Commons

\section{Citation Information}

Williams, Faustine; James, Aimee S.; and Jeanetta, Stephen. 2016. Geographical Location and Stage of Breast Cancer Diagnosis: A Systematic Review of the Literature. Journal of Health Care for the Poor and Underserved. Vol.27(3). 1357-1383. https://doi.org/ 10.1353/hpu.2016.0102 ISSN: 1548-6869

This Article is brought to you for free and open access by the Faculty Works at Digital Commons @ East Tennessee State University. It has been accepted for inclusion in ETSU Faculty Works by an authorized administrator of Digital Commons @ East Tennessee State University. For more information, please contact digilib@etsu.edu. 


\section{Geographical Location and Stage of Breast Cancer Diagnosis: A Systematic Review of the Literature}

\section{Copyright Statement}

Copyright (C) 2017 Meharry Medical College. This article first appeared in Journal of Health Care for the Poor and Underserved 27:3 (2016), 1357-1384. Reprinted with permission by Johns Hopkins University Press.

\section{Comments}

Errata of article published in Journal of Health Care for the Poor and Undeserved, 28(1), February 2017:

https://muse.jhu.edu/article/648782 


\section{PROJECT MUSE}

Geographical Location and Stage of Breast Cancer Diagnosis: A Systematic Review of the Literature

Faustine Williams, Stephen Jeanetta, Aimee S. James

Journal of Health Care for the Poor and Underserved, Volume 27, Number 3, August 2016, pp. 1357-1383 (Article)

Published by Johns Hopkins University Press

DOI: https://doi.org/10.1353/hpu.2016.0102

$\Rightarrow$ For additional information about this article https://muse.jhu.edu/article/628140 


\title{
Geographical Location and Stage of Breast Cancer Diagnosis: A Systematic Review of the Literature
}

\author{
Faustine Williams, PhD, MPH, MS \\ Stephen Jeanetta, $\mathrm{PhD}$ \\ Aimee S. James, $\mathrm{PhD}, \mathrm{MPH}$
}

\begin{abstract}
Objective: To examine systematically the literature on the effect of geographical location variation on breast cancer stage at diagnosis, race/ethnicity, and socioeconomic status. Methods. Eight electronic databases were searched using combination of key words. Of the 312 articles retrieved from the search, 36 studies from 12 countries were considered eligible for inclusion. Results. This review identified 17 (47\%) of 36 studies in which breast cancer patients residing in geographically remote/rural areas had more late-stage diagnosis than urban women. Ten (28\%) studies reported higher proportions of women diagnosed with breast cancer resided in urban than rural counties. Nine (25\%) studies reported no statistically significant association between place of residence and stage at diagnosis for breast cancer patients residing in rural and urban areas. Conclusions. Cancer patients residing in rural and disadvantaged areas were more likely to be diagnosed with distant breast metastasis. Efforts to reduce these inequalities and subsequent mortality are needed.
\end{abstract}

Key words: Breast neoplasm, staging at diagnosis, rural-urban, rural population, urban population, place of residence.

$\mathrm{E}$

xcept for skin cancer, breast cancer is the most frequent malignancy among women in the United States, affecting women across all racial and ethnic groups. In 2015 it was projected that 231,840 new cases of invasive breast cancer were expected to occur among women in the United States (U.S.), and about 2,350 new cases were expected in men. In addition to invasive breast cancer, 60,290 new cases of in situ breast cancer were expected to occur among women in 2015. ${ }^{1,2}$

Studies have indicated that disparities in access to primary care, especially access to screening services such as mammogram and Papanicolaou smear, exist throughout the United States primarily due to uneven distribution of health facilities. ${ }^{3,4}$ Disparities in the prevention and early detection of cancer lead to disparities in cancer outcomes and

\footnotetext{
FAUSTINE WILLIAMS is affiliated with the College of Public Health, Department of Health Services Management and Policy, at East Tennessee State University. AIMEE S. JAMES is affiliated with the Division of Public Health Science, Department of Surgery, at Washington University in St. Louis School of Medicine. STEPHEN JEANETTA is affiliated with the Department of Rural Sociology, Community Development Program and the University of Missouri. Please send correspondence to Faustine Williams, Ph.D., MPH, MS, College of Public Health, Department of Health Services Management and Policy, East Tennessee State University Box 70264 Johnson City, TN 37614-1700; email: FaustineWilliams@ gmail.com; phone: (423) 439-6637; fax: (423) 439-6710.
} 
survival. Much of the disparity in mortality can be attributed to the stage of diagnosis at the time of cancer detection. Research shows that certain groups of people, namely those who are poor, less educated, uninsured, and/or immigrants, are more likely to be diagnosed at a later stage of disease, more likely to receive substandard care, and are more likely to die from cancer. ${ }^{5}$ Nationally, $61 \%$ of White women but only $51 \%$ of Black women were diagnosed with breast cancer at the local stage. ${ }^{6}$ The five-year survival rate for White women diagnosed with breast cancer between 2002 and 2008 was $90 \%$ while the survival rate for Black women was just $78 \%{ }^{6}$

Other studies on cancer survival from cancer in various countries have noted that geographical location is strongly associated with survival and that could also reflect stage at diagnosis and the kind of treatment patients are likely to receive. ${ }^{7-13}$ In contrast, some studies have reported that no significant difference exists between breast cancer stage at diagnosis and place of residence or travel time/distance travel to the nearest mammography facility. ${ }^{14-22}$ The aim of this review was to examine systematically the literature on the effect of geographical location variation on breast cancer stage at diagnosis, race/ethnicity, and socioeconomic status rather than rural-urban differences in mammography use or risk factors for breast cancer development.

\section{Methods}

In the process of identifying studies, searches were conducted in the following bibliographic databases: Academic Search Complete (1984-2013), CINAHL (1982-2013), Compendex and GEOBASE (1969-2013), Medline (1966-2013), PubMed (1951-2013), EMBASE (1947-2013), Cochrane (1993-2013) and Scopus (1960-2013) using key words and phrases. The key words and phrases: breast neoplasm or cancer, staging at diagnosis, rural-urban, rural population, urban population, or place of residence. Additionally, we systematically searched the references sections of all articles retrieved to identify additional citation. There was no limitation of publication date in the search; however, the earliest eligible article was published in 1992. Inclusion criteria were studies comparing the differences in breast cancer stage at diagnosis and geographical place of residence, and were published in English. Based on the inclusion criteria, studies that focus solely on access to health care services, influence of socioeconomic status and race on stage at diagnosis, and geographic differences in treatment and/or survival of breast cancer were excluded.

\section{Results}

Based on the selection criteria established, 36 out of 312 studies from 12 countries remained eligible. ${ }^{11,14-49}$ Figure 1 shows the summary of criteria used for inclusion of eligible studies in this review. Of the eligible papers selected, 23 were from the United States, two each from Australia and New Zealand, and one each from Canada, Denmark, Egypt, Estonia, Italy, Poland, South Africa, Switzerland, and the United Kingdom. Tables 1 and 2 list studies included in this review. Table 1 identifies the type of cancer registry database used and findings, whereas Table 2 focuses on the primary factors addressed and the major conclusions reached by the authors. For the purpose 


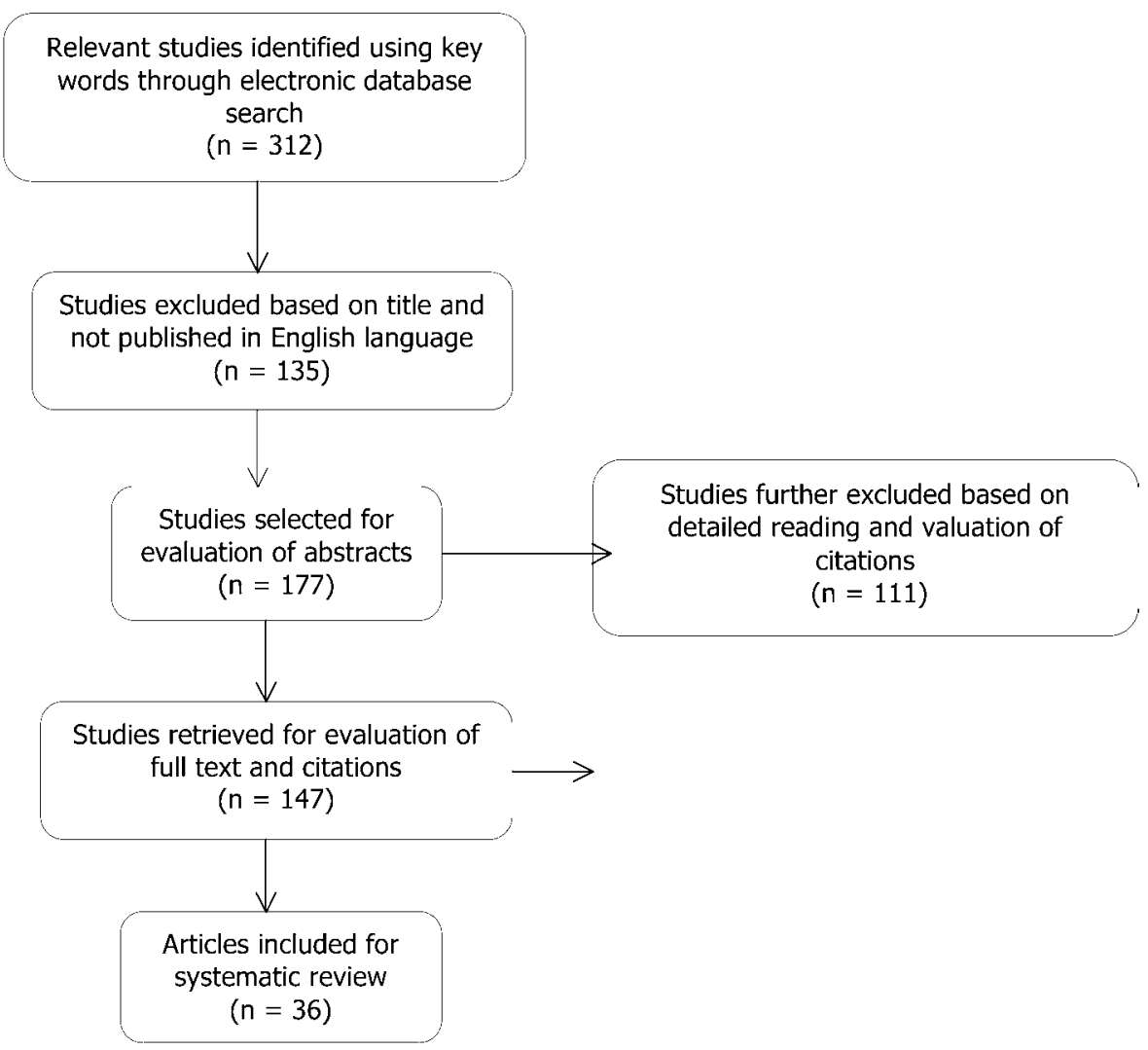

Figure 1. Flow diagram for literature search results and application of eligibility criteria.

of this review, we began analysis by summarizing all of the findings in each study. Second, common themes that emerged in these findings were identified, and finally, the review was structured according to three major general themes. These include: (1) variation by geographic location; (2) variation by race/ethnicity; and (3) variation by socioeconomic status.

Variation by geography or location. Geographic barriers are important for breast cancer patients, especially those who live in rural areas. Over the past decades, numerous studies have confirmed that patients residing in rural and medically underserved areas are more likely to have unstaged tumors and advanced stage breast cancer diagnosis than their urban counterparts. ${ }^{11,23-38}$ However, we found inconsistency in the definition of rural and/or urban. For example, all 23 studies ${ }^{11,16-21,23,25,26,29-32,34,35,38-40,43-46,49}$ from the U.S. used different definitions and measurements for rural and urban. Six studies ${ }^{11,17,18,21,39,40}$ used the rural urban commuting area (RUCA) codes measurement and definition. The RUCA codes classify all census tracts in the U.S. using measures of population density, urbanization, and daily commuting. ${ }^{50}$ The rural urban continuum or Beale code system was used in four studies..$^{20,23,43,46}$ Other definitions such as the urban influence code, U.S. Census Bureau rural urban classification, population density, state-specific minor division, ZIP code and census tract, and federally designated medically underserved 


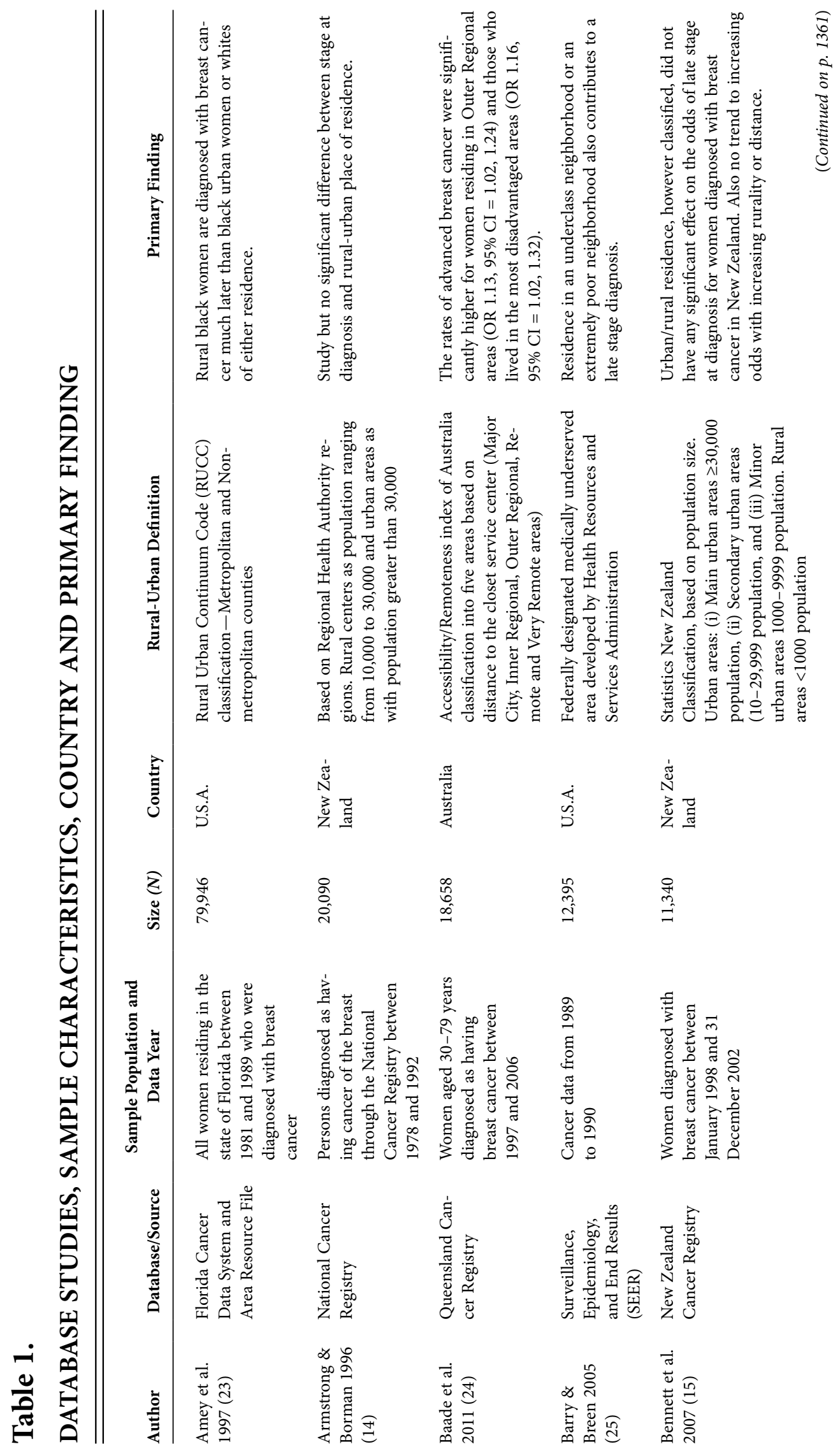




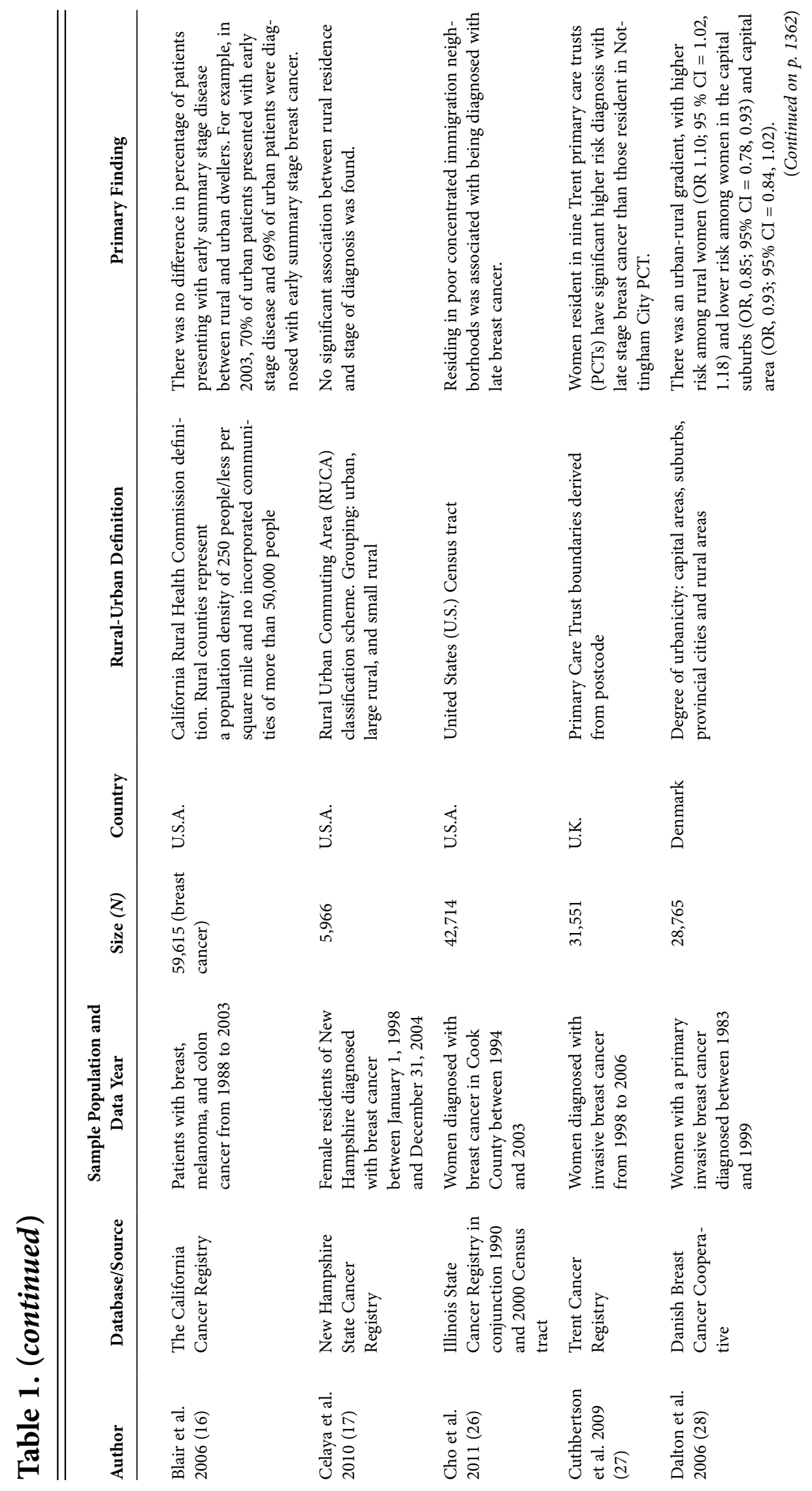




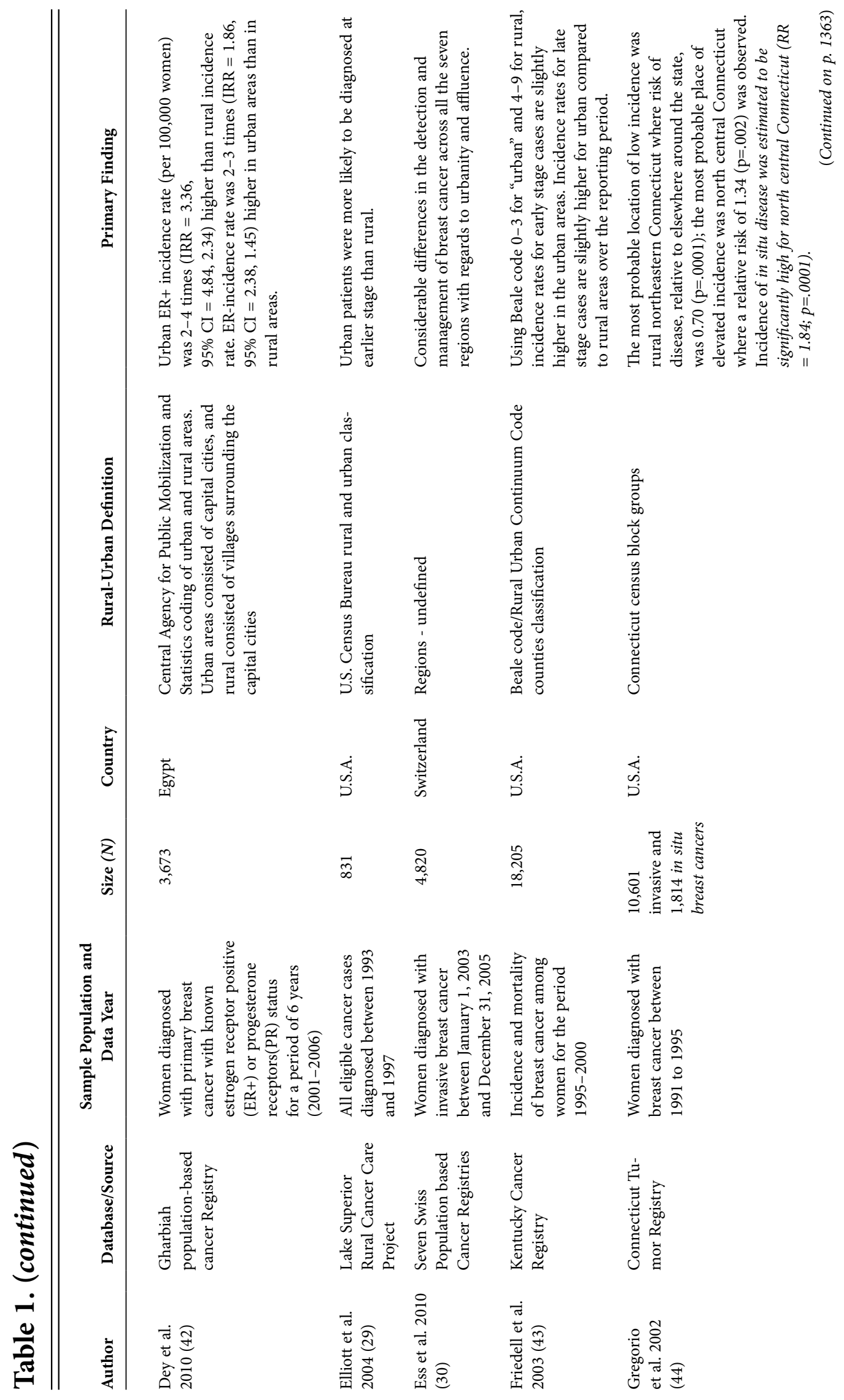




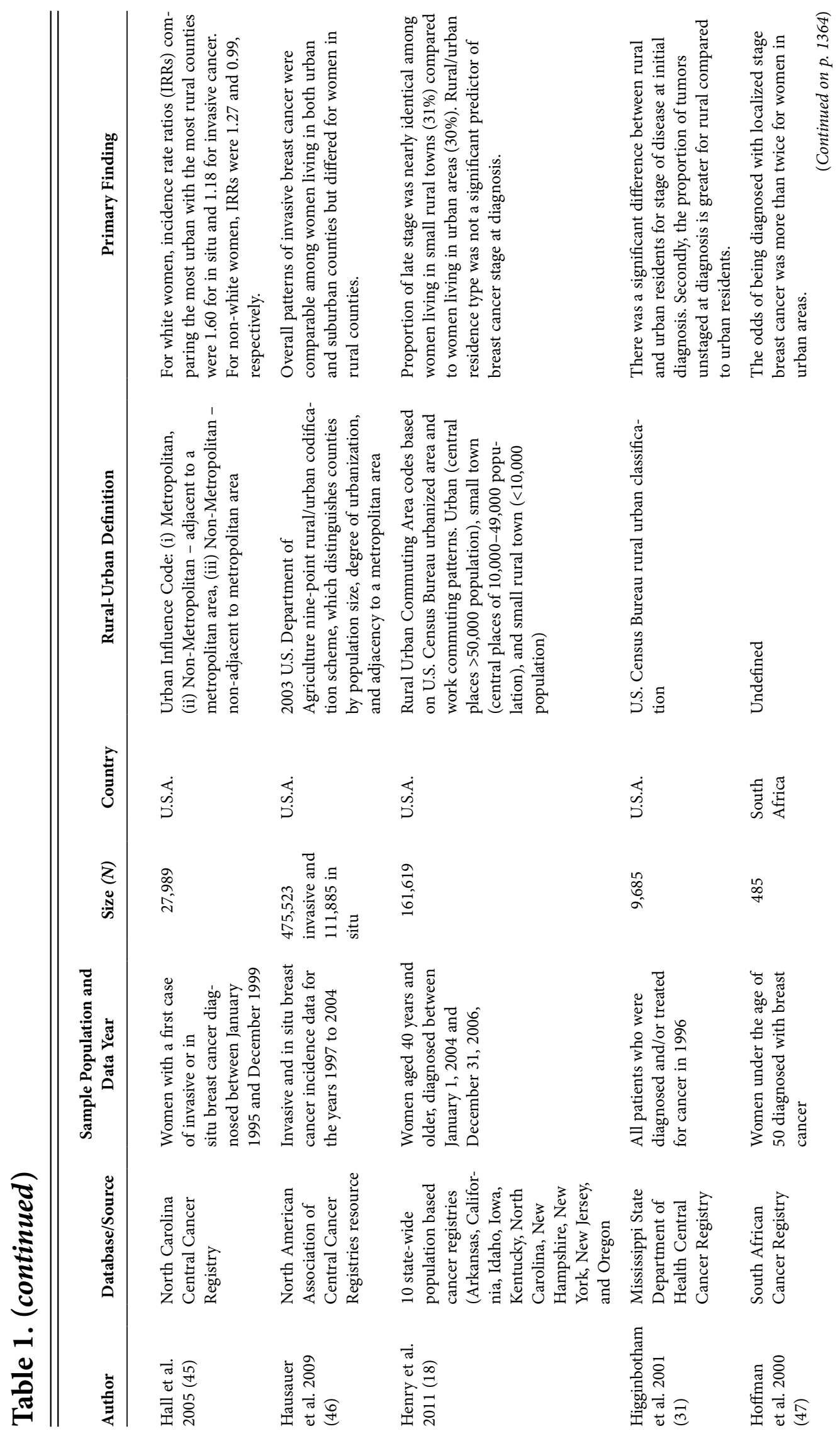




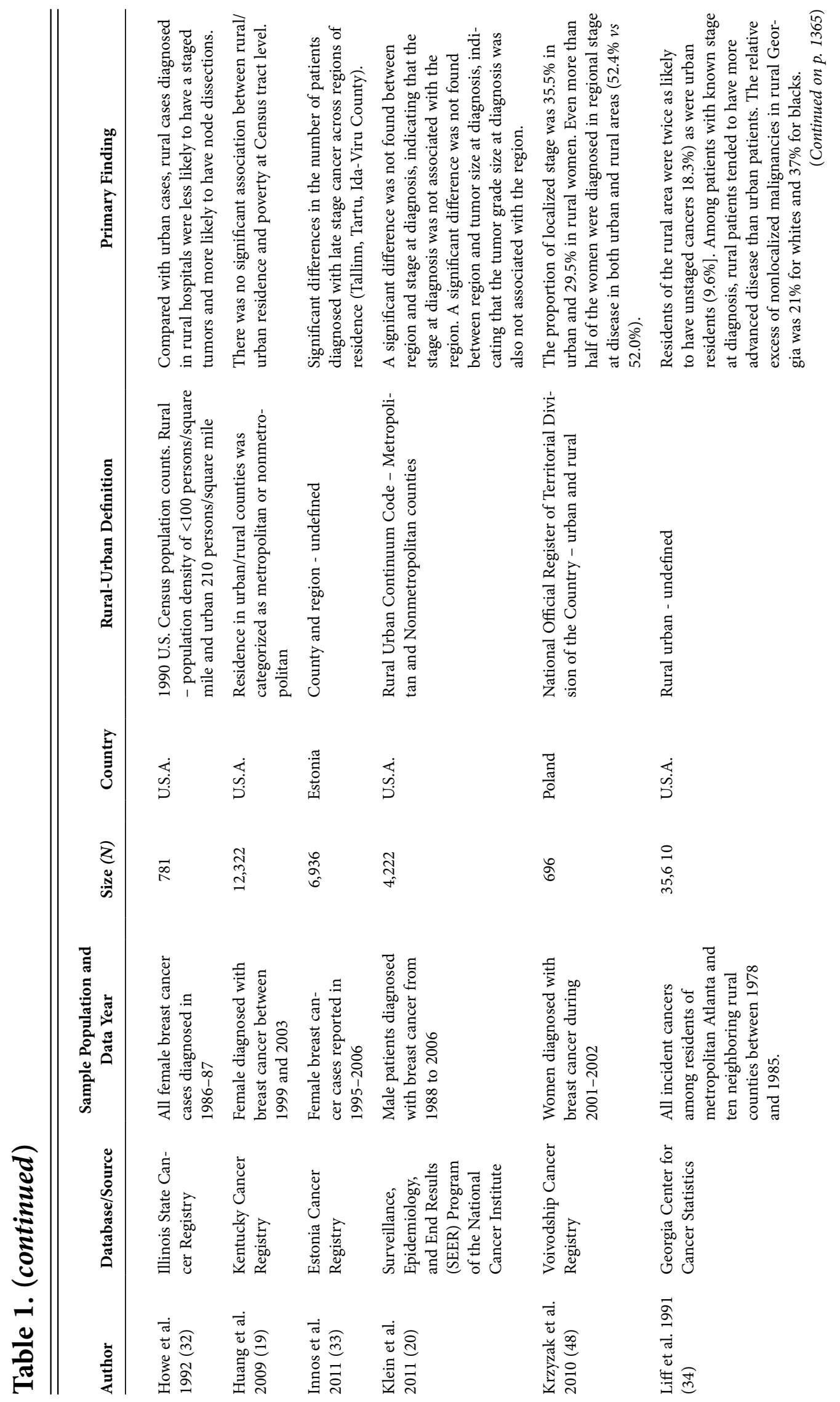




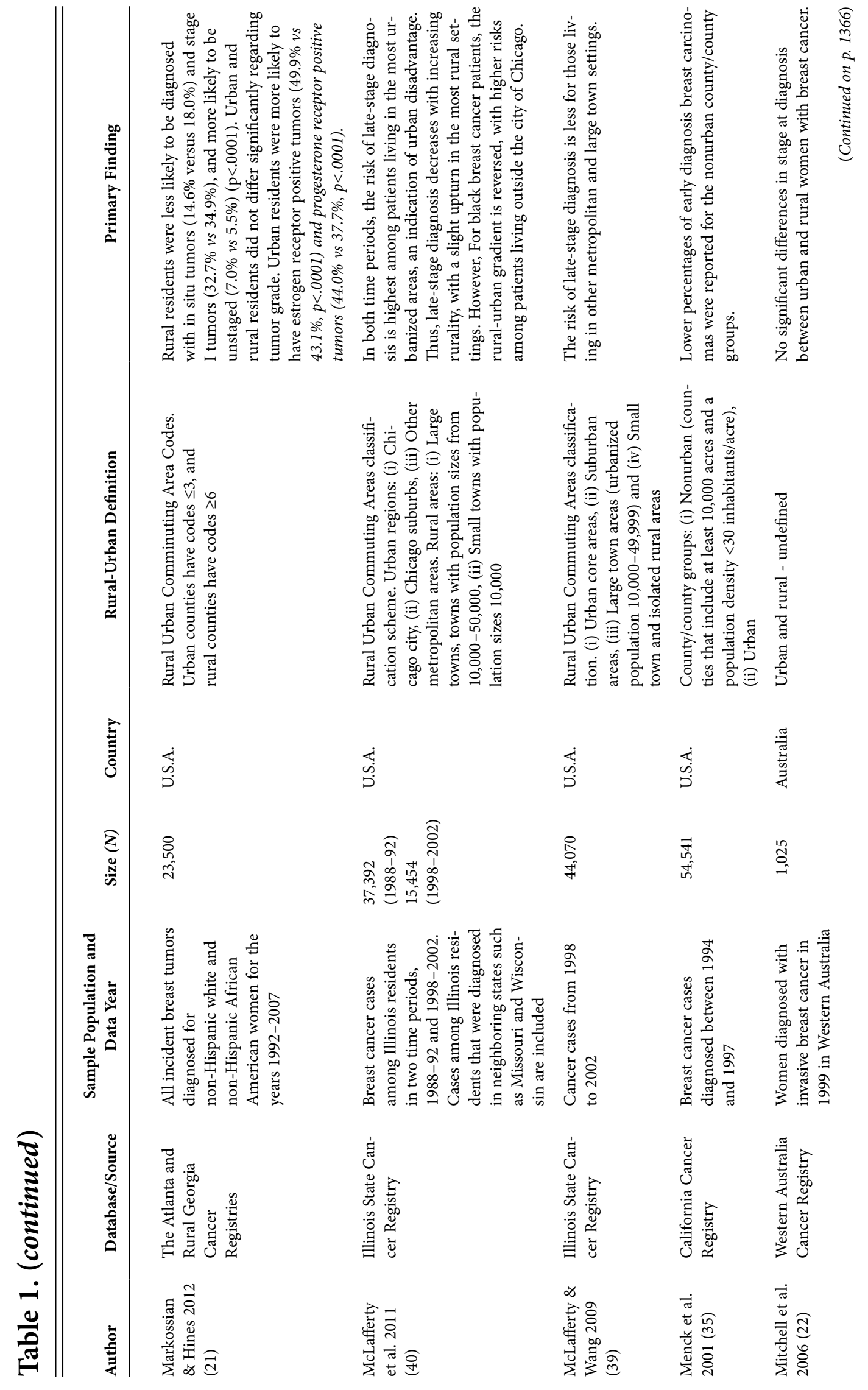




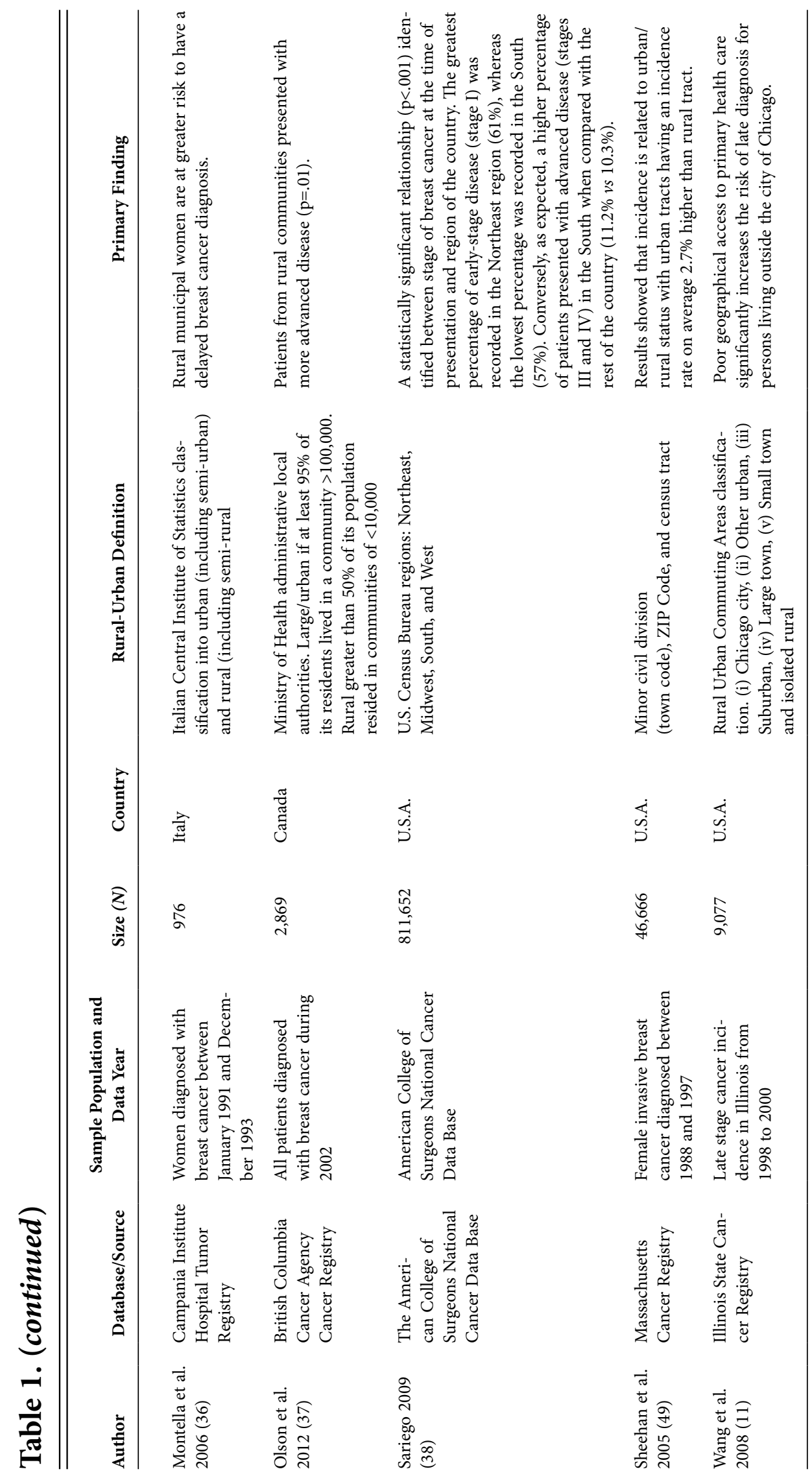




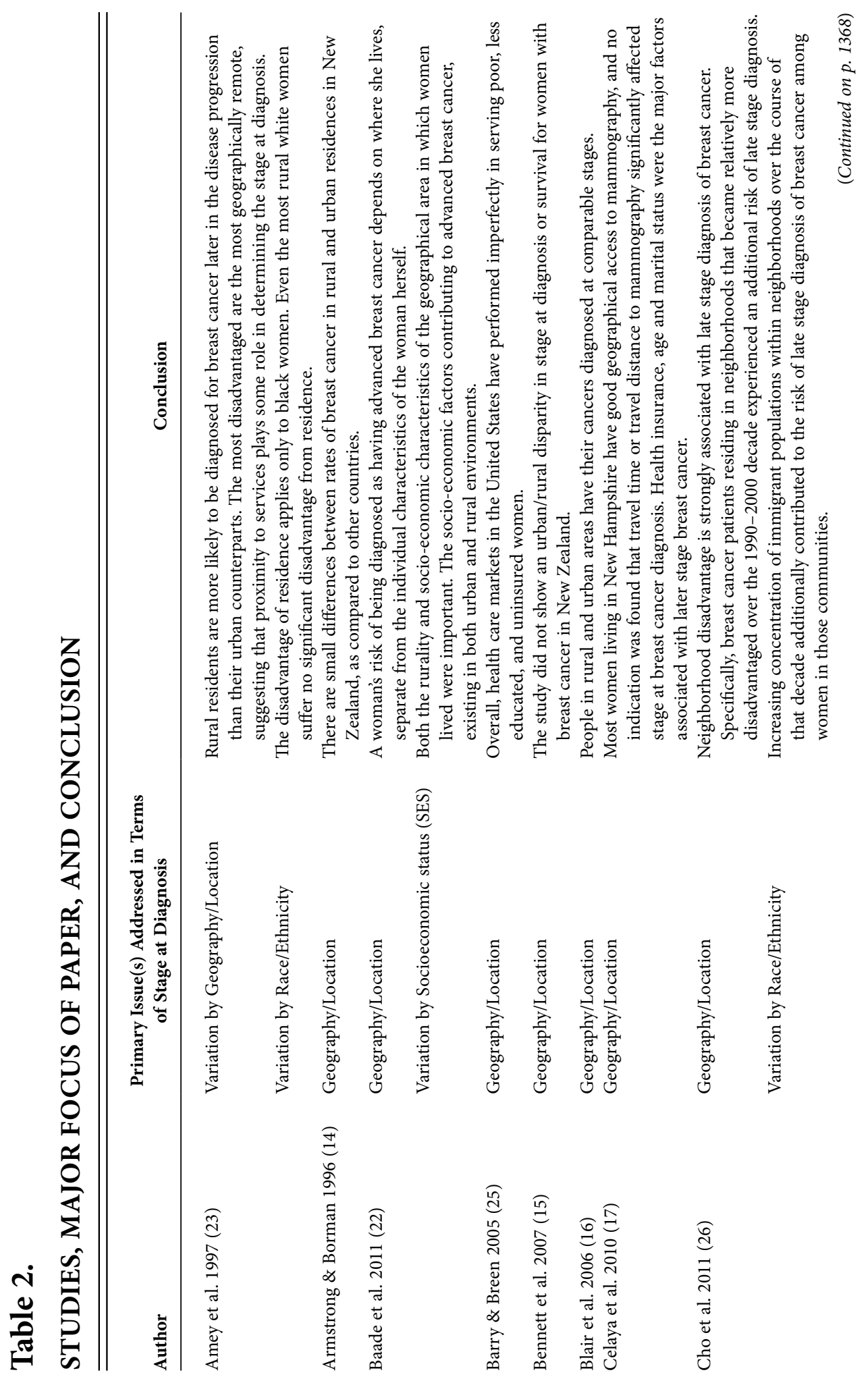




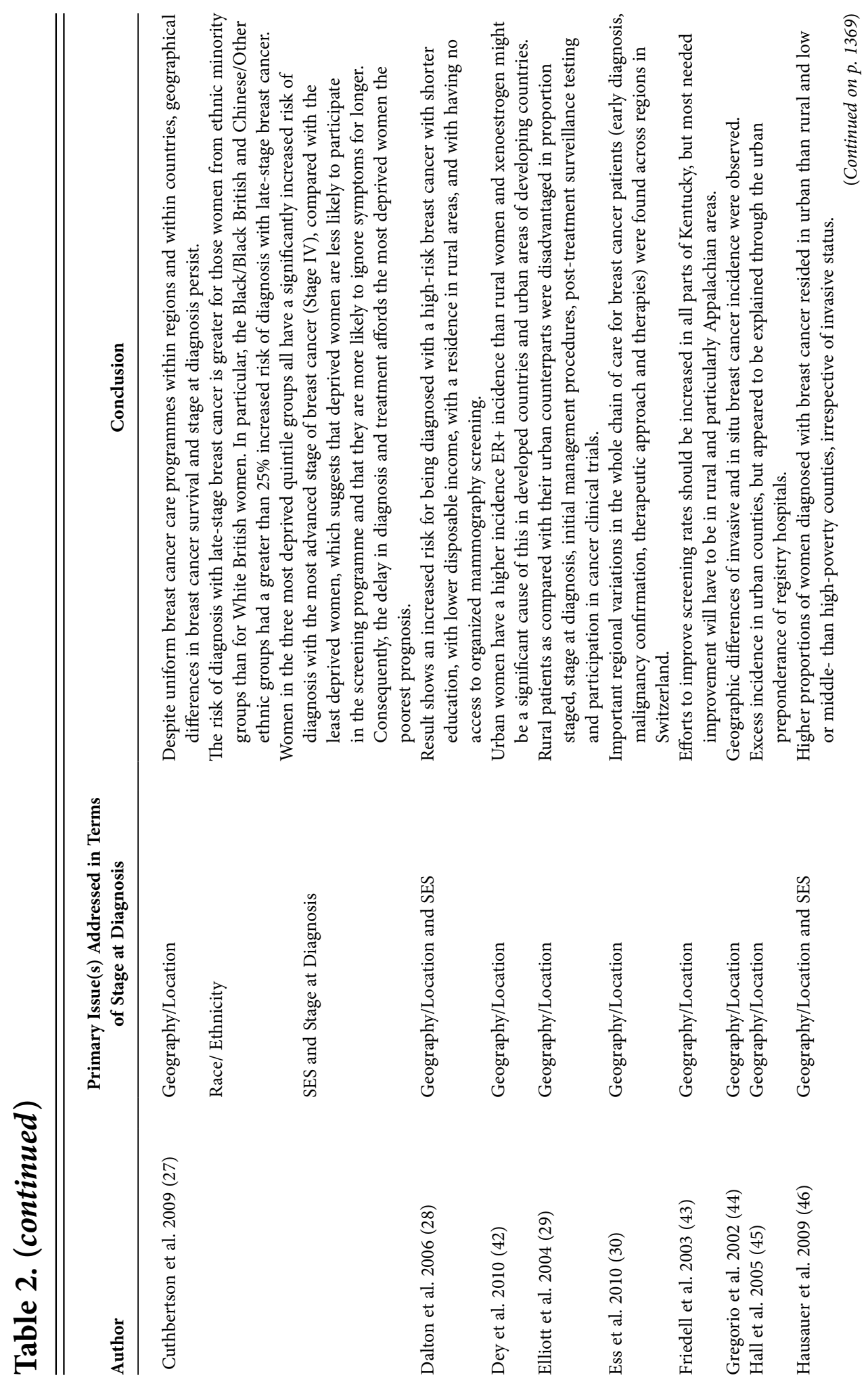




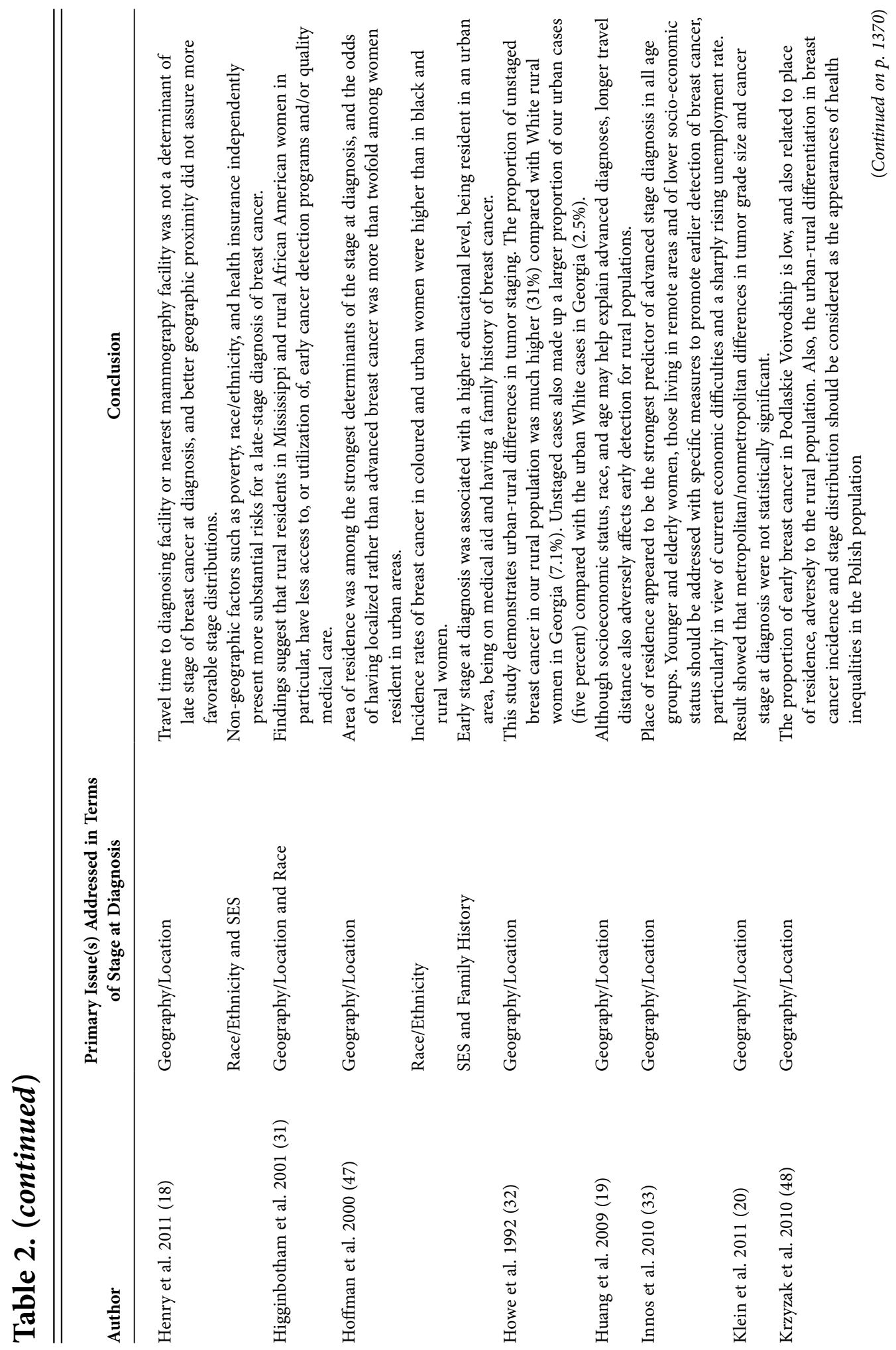




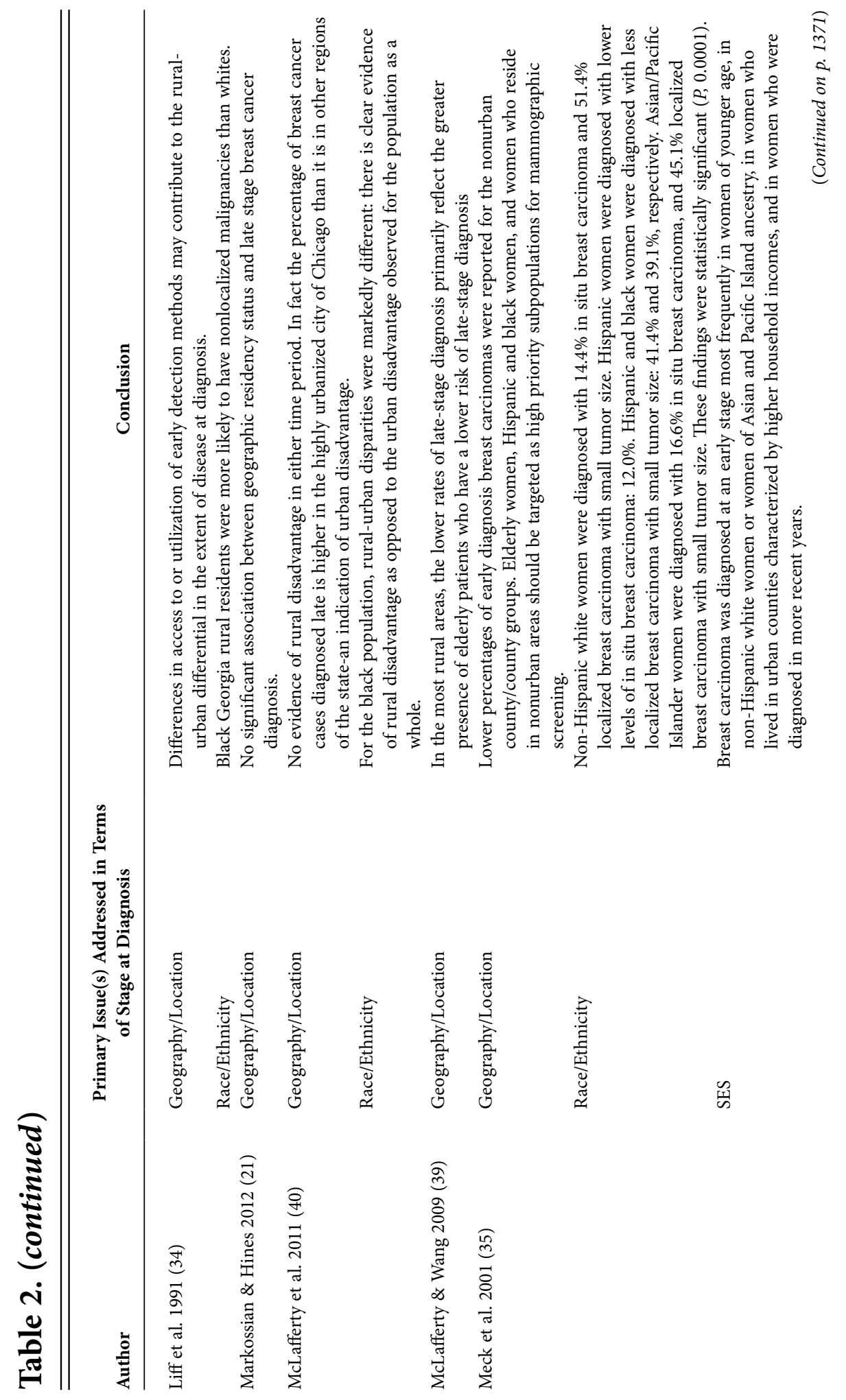




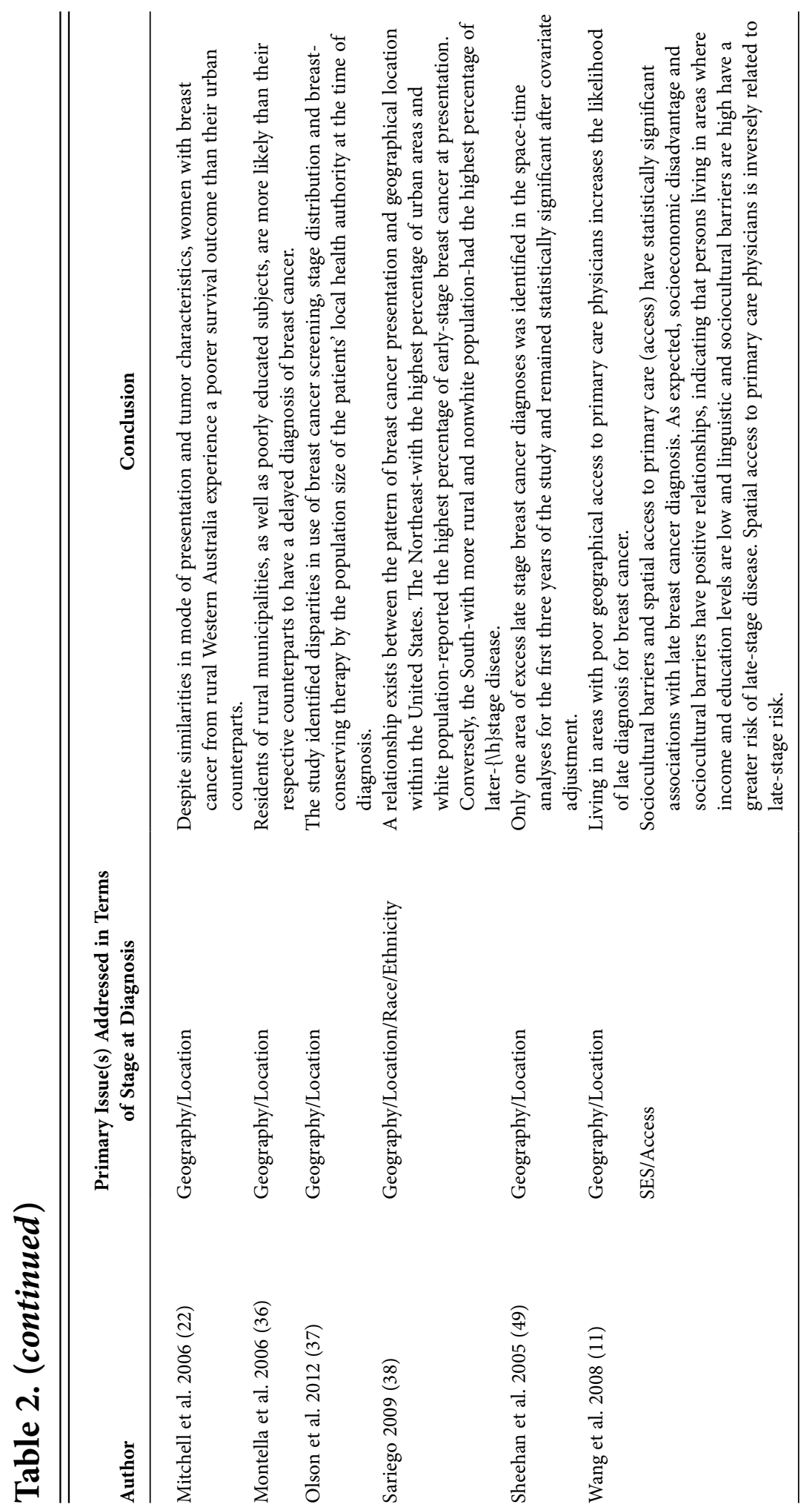


area (among others) were used in 12 studies ${ }^{16,19,25,26,29,31,32,35,38,44,45,49}$ while one study ${ }^{34}$ did not provide information on the measurement type used.

Using a population-based cancer registry data from Georgia, Liff et al. ${ }^{34}[\mathrm{~N}=35,610]$ (rural, urban, not defined) revealed rural patients were twice as likely to have unstaged cancer $(18.3 \%)$ as urban residents (9.6\%). Among patients with known stages, rural residents tended to have more advanced stage of the disease. Similarly in a Danish study, Dalton et al. ${ }^{28}$ [ $\left.\mathrm{N}=28,765\right]$ found that women living in rural areas of Denmark had a $10 \%$ higher odds (OR) of high-risk breast cancer than their urban counterparts (95\% CI: 1.02, 1.18), while those living in the capital suburban areas had a 15\% lower OR (95\% CI: 078, 0.93) than those living in provincial cities.

Long distance travel time to health care services has been shown to influence both access and utilization. ${ }^{11,39,40}$ There is also an assumption that the greater the distance to travel, the higher the incidence of psychological morbidity and the poorer the compliance with treatment. ${ }^{11,41}$ A study by Wang and colleagues ${ }^{11}[\mathrm{~N}=9,077]$ on late-stage breast cancer diagnosis and health care access in Illinois, argued that spatial access to primary care doctors and time travel is critically important in achieving high rates of early breast cancer detection in Illinois and surrounding states. Consequently, living in areas with poor geographical access to primary care physicians increases the likelihood of late diagnosis for breast cancer. ${ }^{11}$

On the other hand, other studies have reported that rural disadvantage does not contribute to distant metastasis breast cancer diagnosis..$^{39,40,42-49}$ Gregorio et al. ${ }^{44}[\mathrm{~N}=$ 12,415] examined geographical differences in breast cancer according to precise geographic coordinates in Connecticut, 1991-1995. Results showed that breast cancer rates were lower than expected for the rural, outermost counties of northeast (risk of disease among residents relative to elsewhere in the state $[R R]$ was .67; $\mathrm{p}=.001$ ) and northwest $(\mathrm{RR}=.88 ; \mathrm{p}=.03)$ Connecticut. However, a higher incidence rate was found for a predominantly suburban/urban county of southwest Connecticut $(R R=1.06 ; p=.004)$.

Additionally Hall et al. ${ }^{45}$ [ $\left.\mathrm{N}=27,989\right]$ used the Urban Influence Code (UIC) measurement to analyze urbanization and breast cancer incidence in North Carolina, 1995-1999. The authors found that, in situ breast cancer incidence rates were highest in the most urbanized counties among Whites (incidence rate ratio (IRR $=1.60$ ) comparing most urban with most rural) and among non-Whites (IRR $=1.27$ for the same comparison). Invasive breast cancer rates were also shown to be higher in the most urban counties for Whites (IRR $=1.18$ comparing most urban with most rural) but not non-Whites (IRR = .99 for the same comparison). In another study, using the Gharbiah population-based cancer registry to determine urban-rural differences in breast cancer incidence in Egypt, Dey et al. ${ }^{42}[\mathrm{~N}=3,673]$ suggest that compared with rural incidences, urban incidences showed that for all hormone receptor status (HRS) was higher in urban areas than rural areas for all age-groups with the urban incidence of estrogen receptor positive $(\mathrm{ER}+)$ cancer being the highest in all age-groups.

In contrast to these findings Amey et al., ${ }^{23}$ Armstrong and Borman, ${ }^{14}$ Bennett et al., ${ }^{15}$ Blair et al., ${ }^{16}$ Celaya et al., ${ }^{17}$ Henry et al., ${ }^{18}$ Huang et al., ${ }^{19}$ Klein et al., ${ }^{20}$ Markossian and Hines, ${ }^{21}$ and Mitchell et al. ${ }^{22}$ found no statistically significant difference in stage of breast cancer and rural-urban geographic location and distance travel to mammography screening facility. Markossian and Hines's. ${ }^{21}[\mathrm{~N}=23,500]$ analysis of Atlanta and 
Rural Georgia Cancer Registry to assess disparities in late stage diagnosis and rural residence found that rural-urban designation was not significantly associated with late stage breast cancer diagnosis, and late stage did not vary significantly across counties $(\mathrm{p}=1.0)$. Additionally, while rural patients had over $22 \%$ increased odds of unknown tumor type compared with urban patients, the association was not statistically significant.

Using the rural urban continuum code (RUCC) classification system definition and Florida cancer data system and area resource file, Amey et al..$^{23}[\mathrm{~N}=79,946]$ analyzed the role of race and residence on stage at breast cancer diagnosis. Results indicated that residents of rural counties that are adjacent to a metropolitan county have the highest percentage $(64.5 \%)$ of women whose breast cancer was detected at an early stage compared with their urban counterparts. This stood in contrast to the findings of Farley and Flannery ${ }^{51}$ who reported that adequately served rural counties were better off than their urban counterparts. The authors also reported that even nonadjacent rural counties had a slightly higher percentage of women diagnosed early (63.1\%) than did urban counties (62.9\%). However, the last difference was not statistically significant, suggesting proximity to services seems not to inhibit the residents of these most rural counties from receiving a timely diagnosis. Celaya et al. ${ }^{17}[\mathrm{~N}=5,966]$ used the Rural Urban Commuting Area codes to classify the rural-urban areas in New Hampshire, and found no significant association between rural residence and stage of breast cancer diagnosis. Similarly, Klein et al. ${ }^{20}[\mathrm{~N}=4,222]$ analyzed differences in male breast cancer stage, tumor size, and stage at diagnosis using metropolitan and non-metropolitan classification and found no statistical differences in proportions of stage or tumor size at diagnosis.

Variation by race or ethnicity. Large disparities in cancer burden and health outcomes exist between Whites and ethnic/racial minorities. For many decades, African American women experienced a lower incidence rates of breast cancer, but a higher mortality rates than White women. ${ }^{1,2,6}$ Nonetheless, recent new evidence concerning disparities in breast cancer has demonstrated that the incidence rates of breast cancer in African American women have increased slightly (by $0.4 \%$ per year) while the rates in White women have remained stable. ${ }^{1,2}$ Rural populations are generally disadvantaged in terms of access to medical care services. ${ }^{23,35,38,40,47}$ Particularly for Black and Hispanic White women, living in rurally remote areas is likely to affect their cancer health prognosis and survival. ${ }^{4,27}$ Amey et al. ${ }^{23}[\mathrm{~N}=79,946]$ revealed that place of residence had a differential impact on stage at diagnosis across racial groups. While the odds of receiving a late diagnosis for Black women in nonadjacent rural counties are approximately $46 \%$ higher than for Black urban residents, it is inconsequential for White women. The study further reported that even low-risk Black women in remote rural counties have approximately a $17 \%$ chance of receiving a late diagnosis, and the $12 \%$ probability for the most disadvantaged Whites is equivalent to the probability of the most advantaged Black group.

In the United Kingdom (U.K.) Cuthbertson et al. ${ }^{27}[\mathrm{~N}=31,551]$ examined racial inequalities in breast cancer diagnosis between ethnic minorities and British White women in the Trent region. Results showed that ethnic minority groups have a significantly increased risk of diagnosis with late stage breast cancer relative to the White British group. For the Black/Black British and Chinese/Other ethnic groups, risk 
of diagnosis with late stage breast cancer is more than $25 \%$ higher $[\mathrm{RR}=1.28(95 \%$ CI: $1.11,1.49)$ and $\mathrm{RR}=1.26(95 \% \mathrm{CI}: 1.04,1.53)]$. Analysis further revealed women residing in nine primary care trusts (PCT) have a significant risk of being diagnosed at late stage, compared with women residing in the Nottingham City PCT. The differences in risk range from an increase of $22 \%$ in Doncaster [RR $=1.22$ (95\% CI: 1:00, $1.48)]$ to $42 \%$ for women in Bassetlaw $[\mathrm{RR}=1.42(95 \% \mathrm{CI}: 1.15,1.77)]$ and Leicester City $[R R=1.41(95 \%$ CI: $1.18,1.17)]$ PCTs. Liff et al. ${ }^{34}[\mathrm{~N}=35,610]$ also reported that the relative excess of non-localized malignancies in rural Georgia was almost twice for Blacks (37\%) as for Whites (21\%). This finding suggests that for Black and other minority populations, the rural-urban disparities are markedly different. ${ }^{40}$

Consistent with these variations by stage at diagnosis and race, Menck and Mills ${ }^{35}$ [N $=54,541]$, descriptive analysis of the California Cancer Registry (1994-1997) showed that non-Hispanic White women were diagnosed with $14.4 \%$ in situ breast carcinoma and $51.4 \%$ localized breast carcinoma with small tumor size. Hispanic women were diagnosed with lower levels of in situ breast carcinoma (12.0\%). Hispanic and Black women were diagnosed with less localized breast carcinoma with small tumor size: $41.4 \%$ and $39.1 \%$, respectively. Asian/Pacific Islander women were diagnosed with $16.6 \%$ in situ breast carcinoma, and $45.1 \%$ localized breast carcinoma with small tumor size. These differences were statistically significant $(\mathrm{p}=.0001)$.

Geographic location variability in rural vs. urban and White vs. Black populations differs within the U.S. The Northeast regions are considered urban and have the largest proportion of Whites. On the other, the Southeast is predominantly rural has the largest number of African Americans. ${ }^{38,52}$ To assess whether geography matters, Sariego ${ }^{38}[\mathrm{~N}=$ 811,652] used the American College of Surgeons' national cancer database to examine the distribution patterns of breast cancer patterns in the U.S. His findings indicated that a large geographic variation exists in proportion of patients diagnosed in stage with regard to race. Results indicated a statistically significant dependent relationship between race and region with regard to breast cancer tumor size $(\mathrm{p}<.001)$. Results indicated a statistically significant dependent relationship between race and region with regard to breast cancer tumor size $(\mathrm{p}<.001)$. There were more White women in all four regions of the U.S. than Black women. However, when stage at diagnosis was compared across the U.S. as a whole, a higher percentage of the White women (90.1\%) were diagnosed with early stage breast cancer (stages I and II) than of the Black women (85.3\%). These differences were statistically significant $(\mathrm{p}<.001)$. Similarly, in terms of rural or nonurban population distribution, more women lived in the Midwest (23.6\%) than in the South (20.4\%). Even though the Midwest has a larger number of women residing in rural areas than the South, more late stage breast cancer was reported among women in the South than among women in the Midwest. This association was also statistically significant $(\mathrm{p}<.002)$. Finally, in terms of urbanicity, the Northeast has a larger proportion of urban areas as well as White population than the South. Nonetheless, an inverse relationship exists between early stage at diagnosis and the proportion of rural population. ${ }^{38}$ Thus, women residing in rural areas (South and West) experienced more late stage breast cancer diagnosis than those in urban areas.

Variation by socioeconomic status. There is a strong relationship between low socioeconomic status and an increased risk of being on the losing end of health dispari- 
ties. ${ }^{53}$ A study by Adler and Newman ${ }^{53}$ on socioeconomic disparities in health reported that whether assessed by income, level of education, or occupation, socioeconomic status clearly predicts the health status of an individual. These three measurements of socioeconomic status influence minority populations only indirectly, but it remains important to consider these three main SES determinants of health.

In Australia, Baade et al. ${ }^{24}[\mathrm{~N}=18,658]$ analyzed Queensland Cancer Registry data to investigate links between geographic remoteness, area disadvantage, individual-level factors and advanced breast cancer. Results showed that women who lived in the most socioeconomically disadvantaged regions were significantly more likely (OR 1.21, 95\% CI $1.07,1.37$ ) than residents of the most economically advantaged areas to be diagnosed with more advanced breast cancer. Further, when place of residence and socioeconomic status were adjusted, the effect of geographic region/resident and area advantage were statistically significant, and the rates of late detection remained significantly higher for women in the most geographically remote and disadvantaged areas compared with women who lived in the cities. Celaya et al. ${ }^{17}[\mathrm{~N}=5,966]$ and Henry et al. ${ }^{18}[\mathrm{~N}=$ $161,619]$, however, found no association between rural and urban residence and stage at diagnosis. Ceyala et al. ${ }^{17}$ for instance noted that New Hampshire women were more likely to be diagnosed with breast cancer at later stages if they lacked private health insurance $(\mathrm{p}=<.001)$, were not married $(\mathrm{p}=<.001)$ and were older $(\mathrm{p}=<.001)$. There was also a borderline association with diagnosis during non-winter and winter months $(\mathrm{p}=.074)$. Barry and Breen ${ }^{25}[\mathrm{~N}=12,395]$ revealed that late diagnosis was prevalent in socially distressed and medically underserved areas.

Henry et al. ${ }^{18}[\mathrm{~N}=161,619]$ analyzed 10 population-based state cancer registries and suggested that for women living in census tracts with poverty rates greater than $20 \%$, the odds of late stage breast cancer were 1.34 times $(95 \% \mathrm{CI}=1.29,1.39)$ greater than the odds for women living in census tracts with poverty rates less than $5 \%$. Other studies have suggested socioeconomic status and residing in urban areas provide an advantage for early diagnosis. ${ }^{28,35,47}$ Dalton et al. ${ }^{28}[\mathrm{~N}=28,765]$ results showed that the risk for late diagnosis decreased with increasing education, income, and urbanicity in women diagnosed with breast cancer in Denmark. Similarly, Cho et al. ${ }^{26}[\mathrm{~N}=42,714]$, Hoffman et al. ${ }^{47}[\mathrm{~N}=485]$ and Wang et al. ${ }^{11}[\mathrm{~N}=9,077]$ also reported an association between socioeconomic status and late stage breast cancer diagnosis. In a study of the association between changes in immigrant population and the likelihood of distant metastasis stage at diagnosis of breast cancer in Cook County Illinois, Cho et al. ${ }^{26}[\mathrm{~N}=$ 42,714 ] discovered that neighborhood disadvantage is strongly associated with late stage diagnosis of breast cancer. Specifically, breast cancer patients residing in neighborhoods that became relatively more disadvantaged over the 1990-2000 decade experienced an additional risk of late stage diagnosis. ${ }^{26}$ Hoffman and colleagues ${ }^{47}$ also $[\mathrm{N}=485]$ suggested that early stage at diagnosis was associated with a higher educational level, being resident in an urban area, on medical aid and having a family history of breast cancer. Similarly, Wang et al. ${ }^{11}[\mathrm{~N}=9,077]$ revealed that socioeconomic disadvantage and sociocultural barriers have positive relationships indicating that people living in areas where income and education levels are low and linguistic and sociocultural barriers are high have a greater risk of late stage disease compared with those in high socioeconomic neighborhoods. 


\section{Discussion}

Disparities in breast cancer between White and Black have been well documented over the years. Causes of these disparities have been linked to social, behavioral, and economic factors such as persistent inequalities in access to care, unhealthy environments, and racial discrimination. ${ }^{11,41,54-57}$ Our systematic review identified 17 (47\%) of 36 studies in which breast cancer patients residing in geographically remote/rural areas had a distant metastasis than urban women. Ten (28\%) studies reported higher proportions of women diagnosed with breast cancer resided in urban than rural counties. Nine (25\%) studies on the other hand, reported no statistically significant effect association between place of residence and stage at diagnosis for women residing in rural and urban areas.

It is clear from the review that, compared with urban residents, rural residents with breast cancer faced unique experiences and challenges with regard to diagnosis. For example, the studies that reported a significant difference in the distant metastasis of the disease between urban and rural patients indicated uniformly that rural breast cancer patients were less likely to be diagnosed with early stage breast cancer due to difficulty accessing cancer screening services in rural areas. ${ }^{11,23-38}$ Additionally, rural patients are more likely to travel greater distances for screening mammography to receive primary breast cancer treatment, and to stay away from home during this treatment, which may factor into why women in rural areas were more likely to be detected with late stage breast cancer in these studies. ${ }^{11,33,4142,55}$

Our review of the studies further demonstrated the ever-increasing racial disparities in breast cancer stage at diagnosis between African American and White women. This literature review suggests that-irrespective of place of residence-African American women were more likely to be diagnosed with later stage breast cancer compared with White women. All $10^{39,40,42-49}$ studies that reported the risk for late stage diagnosis was highest among patients living in urban and metropolitan areas suggest that for Black breast cancer patients the rural-urban difference was reversed. Additionally, when analysis was examined within urban areas among Black women and White women, differences still remained statistically significant in terms of place and socioeconomic status. Similar findings were reported in nine ${ }^{14-22}$ studies that showed no significant difference between stage at diagnosis and rural-urban place of residence.

Our findings further suggest that geographical differences exist not only between rural and urban areas, but also within urban areas in terms of socioeconomic status and stage at breast cancer diagnosis. Generally, socioeconomically disadvantaged populations may experience reduced access to medical care. In addition, lack of health insurance, limited access to care, and lower rates of cancer screening among residents of rural and more disadvantaged areas may account for their higher rates of late stage cancer diagnoses. In terms of race and minority populations, disparities in neighborhood conditions, lower education level, and income may reflect inequities in health care access, cancer screening, and treatment.

Overall, this review suggests that remote rural breast cancer patients are diagnosed at a more advanced stage of the disease than their urban counterparts. At the same time, 
our literature review also pointed to the continuing debate regarding the difficulty in defining and measuring rurality in America. According to Berk et al. ${ }^{58}$ almost one fifth of the U.S. population lives in a rural area, but defining what constitutes rural or urban America is complex. As noted by Brown and Schafft ${ }^{59}$ the word rural is ambiguous: there is no consensus among researchers and policymakers about how to define it or how to classify localities. Over two dozen definitions that are currently in use by various agencies. The use of various definitions reflects the multidimensionality of these concepts-the defining criteria can be population size, population density, administrative boundaries, proximity to urban settings, and economic activities. In addition, researchers and policy makers face several challenges when defining or classifying rural and urban, such as defining thresholds and building blocks (geographic unit), and data availability. ${ }^{60-62}$ This issue became evident in the two Georgia studies that used the same database but came to different conclusion on their findings. For instance, an earlier study by Liff et al. ${ }^{34}$ showed that the risk for advanced stage diagnosis for rural women were more than twice when compared with urban women. On the other hand, a recent follow up study by Markossian and Hines ${ }^{21}$ did not find a significant association between geographic location and late stage breast cancer diagnosis.

This evidence-based review of the literature on geographical location variation on breast cancer stage at diagnosis, race/ethnicity, and socioeconomic status has some limitations. The first relates to differences in definition and measurement for rural and urban in each study. While we believe the variability in measurement might not have affected the results greatly, using a standardized definition across board would have eliminated any confusion. Secondly, the review was limited only to studies that were published in English. This means potential publications meeting the established inclusion, but in other languages were excluded from the review.

Conclusions and future directions. Our study investigated rural-urban differences in the breast cancer stage at diagnosis over the years. Thirty six (36) studies from 12 countries around the world were identified and we provided a comprehensive summary on variations in diagnosis and stage between rural and urban populations. This review suggests that there are inequalities associated with geographical place, race/ethnicity, and stage at diagnosis of breast cancer all over the world. Overall, breast cancer patients residing in rural, remote, and socioeconomically disadvantaged neighborhoods were more likely to be diagnosed with distant breast metastasis. At the same time, a large geographic variations exists in the proportions of sub-populations-such as African American, Hispanic and White women-living in rural areas. Minority women were more likely to be diagnosed at advanced stage compared with their White counterparts irrespective of geographical place of residence.

Given that geographic access is an essential determining factor of a patient's treatment-seeking behavior, it is important to study and develop measures of spatial availability and accessibility of health care facilities for rural areas (and to define the terms rural and urban carefully and consistently). We suggest future studies on breast cancer stage at diagnosis and geographic place of residency address these issues as a way to understand more fully the difference in stage at diagnosis between rural remote (nonmetropolitan) and urban metropolitan areas. 


\section{Acknowledgments}

The study is supported by the Transdisciplinary Research on Energetics and Cancer (TREC) Center at Washington University in St. Louis. The TREC Center is funded by the National Cancer Institute at National Institutes of Health (U54 CA155496).

\section{References}

1. American Cancer Society. Cancer facts \& figures 2015. Atlanta: GA, American Cancer Society, 2015. Available at: http://www.cancer.org/acs/groups/content/@editorial /documents/document/acspc-044552.pdf.

2. DeSantis CE, Fedewa SA, Goding Sauer A, et al. Breast cancer statistics, 2015: Convergence of incidence rates between Black and White women. CA Cancer J Clin. 2016 Jan-Feb;66(1):31-42. Epub 2015 Oct 29.

http://dx.doi.org/10.3322/caac. 21320

PMid:26513636

3. Lorenzo-Luaces Alvarez P, Guerra-Yi ME, Faes C, et al. Spatial analysis of breast and cervical cancer incidence in small geographical areas in Cuba, 1999-2003. Eur J Cancer Prev. 2009 Sep;18(5):395-403.

http://dx.doi.org/10.1097/CEJ.0b013e32832f9b93

PMid:19609213

4. Williams F, Jeanetta S, O'Brien DJ, et al. Rural-urban differences in female breast cancer diagnosis in Missouri. Rural Remote Health. 2015 Jul-Sep;15(3):3063. Epub 2015 Jul 29.

PMid:26223824

5. Siminoff L, Ross L. Access and equity to cancer care in the USA: a review and assessment. Postgrad Med J. 2005 Nov;81(961):674-9.

http://dx.doi.org/10.1136/pgmj.2005.032813

PMid:16272229 PMCid:PMC1743395

6. American Cancer Society. Cancer facts \& figures for African Americans 2013-2014. Atlanta, GA: American Cancer Society, 2013. Available at: http://www.cancer.org/acs /groups/content/@epidemiologysurveilance/documents/document/acspc-036921.pdf.

7. Merkin SS, Stevenson L, Powe N. Geographic socioeconomic status, race, and advancedstage breast cancer in New York City. Am J Public Health. 2002 Jan;92(1):64-70. http://dx.doi.org/10.2105/AJPH.92.1.64 PMid:11772763 PMCid:PMC1447390

8. Brameld KJ, Holman CDJ. The effect of locational disadvantage on hospital utilisation and outcomes in Western Australia. Health Place. 2006 Dec;12(4):490-502. Epub 2005 Sep 19.

http://dx.doi.org/10.1016/j.healthplace.2005.08.014

PMid:16181798

9. Jones AP, Haynes R, Sauerzapf V, et al. Travel times to health care and survival from cancers in Northern England. Eur J Cancer. 2008 Jan;44:269-74. Epub 2007 Sep 20. http://dx.doi.org/10.1016/j.ejca.2007.07.028

PMid:17888651

10. Onega T, Duell E J, Shi X, et al. Geographic access to cancer care in the U.S. Cancer. 2008 Feb 15;112(4):909-18.

11. Wang F, McLafferty S, Escamilla V, et al. Late-stage breast cancer diagnosis and health care access in Illinois. Prof Geogr. 2008 Feb;60(1):54-69. 
http://dx.doi.org/10.1080/00330120701724087

PMid:18458760 PMCid:PMC2367325

12. Meliker JR, Jacquez GM, Goovaerts P, et al. Spatial cluster analysis of early stage breast cancer: a method for public health practice using cancer registry data. Cancer Causes Control. 2009 Sep;20(7):1061-9. Epub 2009 Feb 15.

http://dx.doi.org/10.1007/s10552-009-9312-4

PMid:19219634 PMCid:PMC4337842

13. Jones AP, Haynes R, Sauerzapf V, et al. Travel time to hospital and treatment for breast, colon, rectum, lung, ovary and prostate cancer. Eur J Cancer. 2008 May;44(7):992-9. Epub 2008 Mar 28.

http://dx.doi.org/10.1016/j.ejca.2008.02.001

PMid:18375117

14. Armstrong W, Borman B. Breast cancer in New Zealand: trends, patterns, and data quality. NZ Med J. 1996 Jun 28;109:221-4.

PMid:8769030

15. Bennett H, Marshall R, Campbell I, et al. Women with breast cancer in Aotearoa New Zealand: the effect of urban versus rural residence on stage at diagnosis and survival. NZ Med J. 2007 Nov 30;120(1266):U2831.

PMid:18264200

16. Blair SL, Sadler GR, Bristol R, et al. Early cancer detection among rural and urban Californians. BMC Public Health. 2006 Jul 26;6:194.

http://dx.doi.org/10.1186/1471-2458-6-194

PMid:16869975 PMCid:PMC1544333

17. Celaya MO, Berke EM, Onega TL, et al. Breast cancer stage at diagnosis and geographic access to mammography screening (New Hampshire, 1998-2004). Rural Remote Health. 2010 Apr-Jun;10(2):1361. Epub 2010 Apr 23.

PMid:20438282

18. Henry KA, Boscoe FP, Johnson CJ, et al. Breast cancer stage at diagnosis: is travel time important? J Community Health. 2011 Dec;36(6):933-42.

http://dx.doi.org/10.1007/s10900-011-9392-4

PMid:21461957

19. Huang B, Dignan D, Han D, et al. Does distance matter? Distance to mammography facilities and stage at diagnosis of breast cancer in Kentucky. J Rural Health. 2009 Fall;25(4):366-71.

http://dx.doi.org/10.1111/j.1748-0361.2009.00245.x

PMid:19780916

20. Klein J, Ji M, Rea NK, et al. Differences in male breast cancer stage, tumor size at diagnosis, and survival rate between metropolitan and nonmetropolitan regions. Am J Mens Health. 2011 Sep;5(5):430-7. Epub 2011 Mar 16.

http://dx.doi.org/10.1177/1557988311400403

PMid:21411477

21. Markossian TW, Hines RB. Disparities in late stage diagnosis, treatment, and breast cancer-related death by race, age, and rural residence among women in Georgia. Women Health. 2012;52(4):317-35.

http://dx.doi.org/10.1080/03630242.2012.674091

PMid:22591230

22. Mitchell KJ, Fritschi L, Reid A, et al. Rural-urban differences in the presentation, management and survival of breast cancer in Western Australia. Breast. 2006 Dec;15(6):769-76. Epub 2006 Jun 9. 
http://dx.doi.org/10.1016/j.breast.2006.04.001

PMid:16765049

23. Amey $\mathrm{CH}$, Miller MK, Albrecht SL. The role of race and residence in determining stage at diagnosis of breast cancer. J Rural Health. 1997 Spring;13(2):99-108.

http://dx.doi.org/10.1111/j.1748-0361.1997.tb00939.x PMid:10169323

24. Baade PD, Turrell G, Aitken JF. Geographic remoteness, area-level socio-economic disadvantage and advanced breast cancer: a cross-sectional, multilevel study. J Epidemiol Community Health. 2011 Nov;65(11):1037-43. Epub 2011 Jan 30.

http://dx.doi.org/10.1136/jech.2010.114777

PMid:21282144

25. Barry J, Breen N. The importance of place of residence in predicting late-stage diagnosis of breast or cervical cancer. Health Place. 2005 Mar;11:15-29.

http://dx.doi.org/10.1016/j.healthplace.2003.12.002

PMid:15550353

26. Cho YI, Johnson TP, Barrett RE, et al. Neighborhood changes in concentrated immigration and late stage breast cancer diagnosis. J Immigr Minor Health. 2011 Feb;13(1):9-14.

http://dx.doi.org/10.1007/s10903-010-9339-3

PMid:20232147

27. Cuthbertson SA, Goyder EC, Poole J. Inequalities in breast cancer stage at diagnosis in the Trent region, and implications for the NHS Breast Screening Programme. J Public Health (Oxf). 2009 Sep;31(3):398-405. Epub 2009 May 7.

http://dx.doi.org/10.1093/pubmed/fdp042

PMid:19423544

28. Dalton SO, During M, Ross L, et al. The relation between socioeconomic and demographic factors and tumour stage in women diagnosed with breast cancer in Denmark, 1983-1999. Brit J Cancer. 2006 Sep;95(5):653-9. Epub 2006 Aug 8.

http://dx.doi.org/10.1038/sj.bjc.6603294

PMid:16909141 PMCid:PMC2360690

29. Elliott TE, Elliott BA, Renier CM, et al. Rural-urban differences in cancer care: results from the Lake Superior Rural Cancer Care Project. Minn Med. 2004 Sep;87(9): 44-50.

PMid:15495877

30. Ess S, Savidan A, Frick H, et al. Geographic variation in breast cancer care in Switzerland. Cancer Epidemiol. 2010 Apr;34:116-21. Epub 2010 Feb 24.

http://dx.doi.org/10.1016/j.canep.2010.01.008

PMid:20185382

31. Higginbotham JC, Moulder J, Currier M. Rural v. urban aspects of cancer: first year data from the Mississippi Central Cancer Registry. Fam Community Health. 2001 Jul;24(2):1-9.

http://dx.doi.org/10.1097/00003727-200107000-00003

PMid:11373161

32. Howe HL, Katterhagen JG, Yates J, et al. Urban-rural differences in the management of breast cancer. Cancer Causes Control. 1992 Nov;3(6):533-9.

http://dx.doi.org/10.1007/BF00052750

PMid:1420856

33. Innos K, Magi M, Tekkel M, et al. Place of residence predicts breast cancer stage at diagnosis in Estonia. Eur J Public Health. 2011 Jun;21(3):376-80. Epub 2010 Mar 17. 
http://dx.doi.org/10.1093/eurpub/ckq025

PMid:20237172

34. Liff JM, Chow WH, Greenberg RS. Rural urban differences in stage at diagnosis. Possible relationship to cancer screening. Cancer. 1991 Mar;67(5):1454-9. http://dx.doi.org/10.1002/1097-0142(19910301)67:5<1454::AID-CNCR2820670533 $>3.0 . \mathrm{CO} ; 2-\mathrm{K}$

35. Menck HR, Mills PK. The influence of urbanization, age, ethnicity, and income on the early diagnosis of breast carcinoma. Cancer. 2001 Sep;92(5):1299-304. http://dx.doi.org/10.1002/1097-0142(20010901)92:5<1299::AID-CNCR1451>3.0 .CO;2-7

36. Montella M, Biondi E, De Marco M, et al. Sociodemographic factors associated with the diagnostic staging of breast cancer in southern Italy. Cancer. 1995 Nov 1;76(9):1585-90.

http://dx.doi.org/10.1002/1097-0142(19951101)76:9<1585::AID-CNCR2820760914 $>3.0 . \mathrm{CO} ; 2-\mathrm{O}$

37. Olson RA, Nichol A, Caron NR, et al. Effect of community population size on breast cancer screening, stage distribution, treatment use and outcomes. Can J Public Health. 2012 Jan-Feb;103(1):46-52.

PMid:22338328

38. Sariego J. Patterns of breast cancer presentation in the United States: does geography matter? Am J Surg. 2009 Jul;75(7):545-9; discussion 549-50.

39. McLafferty S, Wang F. Rural reversal? Rural-urban disparities in late-stage cancer risk in Illinois. Cancer. 2009 Jun 15;115(12):2755-64.

http://dx.doi.org/10.1002/cncr.24306

PMid:19434667 PMCid:PMC2774239

40. McLafferty S, Wang F, Luo L, et al. Rural-urban inequalities in late-stage breast cancer: Spatial and social dimensions of risk and access. Environ Plann B Plann Des. 2011 Aug;38(4):726-40.

http://dx.doi.org/10.1068/b36145

PMid:23335830 PMCid:PMC3547633

41. Campbell NC, Elliot AM, Sharp L, et al. Rural factors and survival from cancer: analysis of Scottish cancer registrations. Brit J Cancer. 2000 Jun;82(11):1863-6.

http://dx.doi.org/10.1054/bjoc.1999.1079

PMid:10839303 PMCid:PMC2363217

42. Dey S, Soliman AS, Hablas A, et al. Urban-rural differences in breast cancer incidence by hormone receptor status across 6 years in Egypt. Breast Cancer Res Treat. 2010 Feb;120(1):149-60. Epub 2009 Jun 23.

http://dx.doi.org/10.1007/s10549-009-0427-9

PMid:19548084 PMCid:PMC2808467

43. Friedell GH, Linville LH, Sorrell CL, et al. Kentucky breast cancer report card. J Ky Med Assoc. 2003 Oct;101(10):449-54.

PMid:14593789

44. Gregorio DI, Kulldorff M, Barry L, et al. Geographic differences in invasive and in situ breast cancer incidence according to precise geographic coordinates, Connecticut, 1991-95. Int J of Cancer. 2002 Jul 10;100(2):194-8.

http://dx.doi.org/10.1002/ijc.10431

PMid:12115569

45. Hall SA, Kaufman JS, Millikan RC, et al. Urbanization and breast cancer incidence in North Carolina, 1995-1999. Ann Epidemiol. 2005 Nov;15(10):796-803. 
http://dx.doi.org/10.1016/j.annepidem.2005.02.006

PMid:15922628

46. Hausauer AK, Keegan TH, Chang ET, et al. Recent trends in breast cancer incidence in US White women by county-level urban/rural and poverty status. BMC Med. 2009 Jun 26;7:31.

http://dx.doi.org/10.1186/1741-7015-7-31

PMid:19558637 PMCid:PMC2714853

47. Hoffman M, de Pinho H, Cooper D, et al. Breast cancer incidence and determinants of cancer stage in the Western Cape. S Afr Med J. 2000 Dec;90(12):1212-6.

PMid:11234652

48. Krzyzak M, Maslach D, Juczewska M, et al. Differences in breast cancer incidence and stage distribution between urban and rural female population in Podlaskie Voivodship, Poland in years 2001-2002. Ann Agric Environ Med. 2010;17(1):159-62. PMid:20684494

49. Sheehan TJ, DeChello LM. A space-time analysis of the proportion of late stage breast cancer in Massachusetts, 1988 to 1997. Int J Health Geogr. 2005 Jun 8;4:15. http://dx.doi.org/10.1186/1476-072X-4-15

PMid:15943865 PMCid:PMC1180846

50. United States Department of Agriculture (USDA) Economic Research Service. Ruralurban commuting area codes. Washington, DC: USDA, 2014. Available at: http://www .ers.usda.gov/data-products/rural-urban-commuting-area-codes.aspx.

51. Farley TA, Flannery JT. Late-stage diagnosis of breast cancer in women of lower socioeconomic status: public health implications. Am J Public Health. 1989 Nov;79(11):1508-12. http://dx.doi.org/10.2105/AJPH.79.11.1508 PMid:2817162 PMCid:PMC1349803

52. Housing Assistance Council (HAC). Rural research brief: race and ethnicity in rural America. Atlanta, GA: HAC, 2012. Available at: http://ruralhome.nonprofitsoapbox .com/storage/research_notes/rrn-race-and-ethnicity-web.pdf.

53. Adler NE, Newman K. Socioeconomic disparities in health: pathways and policies. Health Aff (Millwood). 2002 Mar-Apr;21(2):60-76.

http://dx.doi.org/10.1377/hlthaff.21.2.60

54. Liburd LC, Giles HW, Mensah GA. Looking through a glass, darkly: eliminating health disparities. Prev Chronic Dis. 2006 Jul;3(3):A72. Epub 2006 Jun 15. PMid:16776873 PMCid:PMC1636715

55. Jordan H, Roderick P, Martin D, et al. Distance, rurality and the need for care: access to health services in South West England. Int J Health Geogr. 2004 Sep 29;3(1):21. http://dx.doi.org/10.1186/1476-072X-3-21

PMid:15456514 PMCid:PMC524184

56. Cromley RG, Cromley EK. Choropleth map legend design for visualizing community health disparities. Int J Health Geogr. 2009 Sep 24;8:52.

http://dx.doi.org/10.1186/1476-072X-8-52 PMid:19778435 PMCid:PMC2760860

57. Peters DH, Garg A, Bloom G, et al. Poverty and access to health care in developing countries. Ann N Y Acad Sci. 2008;1136:161-71. Epub 2007 Oct 22.

http://dx.doi.org/10.1196/annals.1425.011

PMid:17954679

58. Berk M, Feldman J, Schur C, et al. Satisfaction with practice and decision to relo- 
cate: an examination of rural physicians. Bethesda, MD: NORC Walsh Center for Rural Health Analysis. Bethesda: MD, NORC Walsh Center for Rural Health Analysis, 2009. Available at: http://www.norc.org/PDFs/Walsh\%20Center/Main\%20Page /SatisfactionwithPracticeandDecisiontoRelocateAnExaminationofRuralPhysicians.pdf.

59. Brown DL, Schafft KA. Rural people and communities in the 21st century: resilience and transformation. Cambridge, UK: Polity Press, 2011.

60. Flora CB, Flora JL. Rural communities: Legacy and change. 3rd ed. Boulder, CO: Westview Press, 2008.

61. Isserman AM. In the national interest: defining rural and urban correctly in research and public policy. Int Reg Sci Rev. 2005 Oct;28(4):465-499.

http://dx.doi.org/10.1177/0160017605279000

62. Waldorf BS. What is rural and what is urban in Indiana? West Lafayette, IN: Purdue Center for Regional Development, 2007. Available at: https://www.pcrd.purdue.edu /files/media/What-is-Rural-and-What-is-Urban-in-Indiana.pdf.

PMid:18022131 
Errata: Williams F, Jeanetta S, James AS. Geographical Location and Stage of Breast Cancer Diagnosis: A Systematic Review of the Literature. Journal of Health Care for the Poor and Underserved 27 (2016): 1357-1383.

Page 1359: Correct display of diagram is shown here:

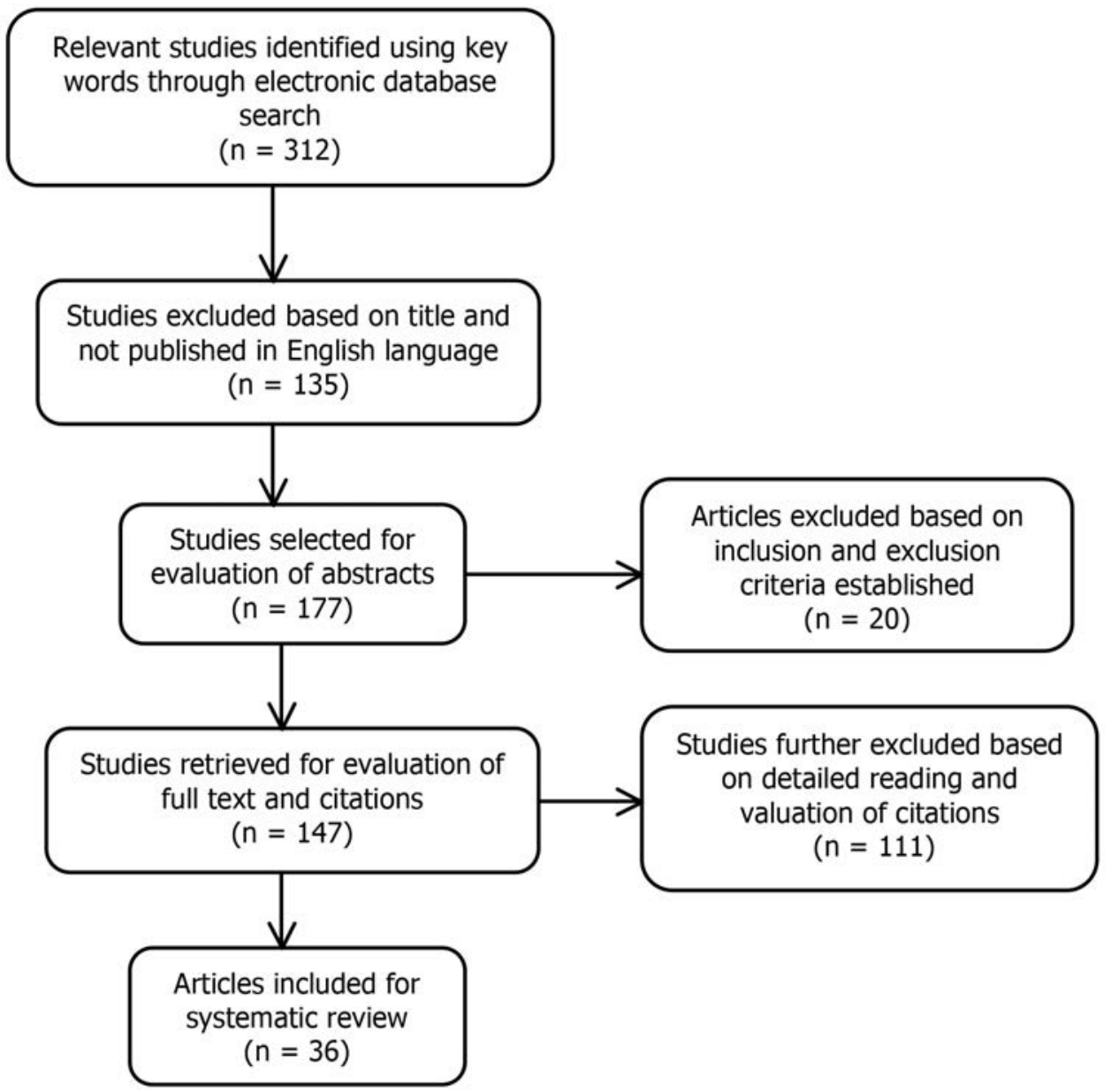

Figure 1. Flow diagram for literature search results and application of eligibility criteria

Page 1377: Table 1: (continued) Elliott et al. 2004 (29). Rural patients as compared with their urban counterparts were disadvantaged in proportion staged, stage at diagnosis, initial management procedures, post-treatment surveillance testing and participation in cancer clinical trials. [Correction: Rural patients compared with their urban counterparts were disadvantaged in proportion of stage at diagnosis, initial management procedures, post-treatment surveillance testing, and participation in cancer clinical trials.] 